\title{
$\mathrm{Zr}$ 基ナノ結晶分散バルク金属ガラスに おける疲労き裂伝ぱ*
}

\author{
1 宇部工業高等専門学校機械工学科 \\ 東北大学金属材料研究所 \\ J. Japan Inst. Metals, Vol. 64, No. 9 (2000), pp. 787-792 \\ (C) 2000 The Japan Institute of Metals
}

藤田和孝 1 井上明久 ${ }^{2}$ 張涛 2

\section{Fatigue Crack Propagation in a Nanocrystalline Zr-Based Bulk Metallic Glass}

\author{
Kazutaka Fujita ${ }^{1}$, Akihisa Inoue ${ }^{2}$ and Tao Zhang ${ }^{2}$ \\ ${ }^{1}$ Department of Mechanical Engineering, Ube National College of Technology, Ube 755-8555 \\ ${ }^{2}$ Institute for Materials Research, Tohoku University, Sendai 980-8577
}

\begin{abstract}
A nanocrystalline $(\mathrm{NC})$ bulk glass $\mathrm{Zr}_{55} \mathrm{Al}_{10} \mathrm{Cu}_{30} \mathrm{Ni}_{5}$ (at\%) which contains nano-scale crystals embedded uniformly in a glassy matrix has both high tensile strength of $1.7 \mathrm{GPa}$ and high ductility. It is therefore expected to find practical application in machines and structures. The fatigue crack propagation behavior of the NC bulk glass was examined. The threshold stress intensity factor range $\Delta K_{\text {th }}$ was about $0.9 \mathrm{MPa} \sqrt{m}$, and the fatigue fracture toughness $K_{\mathrm{fc}}$ was about $13 \mathrm{MPa} \sqrt{m}$. Fatigue crack propagation rate $d a / d n$ was approximately proportional to $\Delta K^{2}$. No significant difference in $d a / d n$ between the NC glassy alloy and single phase amorphous alloys in literature was seen when they are compared on the basis of $\Delta K$ divided by Young's modulus $E$. The $d a / d n$ values were nearly the same as those for steels with the same tensile strength level. The $d a / d n$ values were larger than those for low strength steels, $\mathrm{Al}$ alloys and $\mathrm{T} i$ alloys in the low $d a / d n$ range. When compared with the effective stress intensity factor range $\Delta K_{\text {eff }}$ divided by $E$, the $d a / d n$ values for crystalline alloys were almost coincident with those under different stress ratios for the NC glassy alloy. This indicates that the $d a / d n$ values for the NC glassy alloy can be estimated on the basis of the $d a / d n$ data for crystalline alloys.
\end{abstract}

(Received May 15, 2000; Accepted July 17, 2000)

Keywords: fatigue crack, nanocrystal, bulk metallic glass, amorphous alloy, fracture mechanics, crack closure, effective stress intensity factor range

\section{1. 緒言}

従来, アモルファス金属固体を液体がらの冷却により生成 するには超急冷 $\left(10^{4} \mathrm{~K} / \mathrm{s}\right.$ 程度以上)を要し，そのために厚さ が数十 $\mu \mathrm{m}$ 程度の薄帯材しか作製できなかった1)。しかし 1988年にバルクガラス合金の創製につながる大きなガラス 形成能をもった $\operatorname{Ln}$ (希土類)基合金が筆者の一人でする東北 大学・井上らのグループにより見出され2), その後多くの合 金系で冷却速度が数 K/s 以下と遅い場合にもガラス状態が 維持できる組成が明らかとなり，バルクな金属がラスが作製 可能となった. バルク金属がラスは, 従来からの薄帯アモル ファス金属と同様，機械構造部材として重要な機械的性質 (強度, 勒性)と耐食性に優れているとともに, 薄带と異なり それ単体で強度部材となり点る。さらに最近，このバルク金 属ガラスをガラス遷移点以上炕再加熱後冷却寸る方法等以よ り，ナノ結晶が分散したガラス相を有高るバルク金属ガラス が作製され，これは同組成の単相バルク金属ガラスよりもさ らに大きい引張り強度と勒性を示し ${ }^{3)}$, 実用強度部材候補と

\footnotetext{
*1999年11月21日本金属学会秋期大会に括いて発表
}

して注目されている。

実機の破壊原因の多くはよく知られているよら飞繰返し荷 重下の疲労であり, き裂状欠陷が有る場合火は疲労寿命の多 くはき裂伝ぱ費やされる。そこで本研究では，ナノ結晶分 散バルク金属ガラスの機械構造部材への実用化をめざし, 疲 労き裂伝ぱ特性について検討した。

\section{2. 試 験 方 法}

供試材は，バルク金属ガラス $\mathrm{Zr}_{55} \mathrm{Al}_{10} \mathrm{Cu}_{30} \mathrm{Ni}_{5}($ at \% )を基に アーク溶解鍛造法4によって作製したナノ結晶分散バルク金 属ガラスである．ここで $\mathrm{Zr}$ 基金属がラスを用いたのは，高 強度・高䩗性を有与ることが知られている5ためである。透 過電子影微鏡組織写真を Fig. 1 亿示す. 原子が規則的K並 んだ $3 \mathrm{~nm}$ 程度の結晶部分を原子が不規則に並んだガラス部 分が因えでいる. 引張り強さ $\sigma_{\mathrm{B}}$ は $1.7 \mathrm{GPa}$ ，ヤング率 $E$ は $87 \mathrm{GPa}$ である。な招同組成の単相バルク金属ガラスの $\sigma_{\mathrm{B}}$ は 1.6 1.8 GPa, $E$ は 87 $90 \mathrm{GPa}$ ，切欠き材の破㙘勒性值 $K_{\mathrm{IC}}$ は $68 \mathrm{MPa} \sqrt{m^{6}}$ である。

試験片は, ASTM 推奨(規格 E647)の中央き裂引張り (CCT) 試験片とし，形状を Fig. 2 に示す. 同形状に機械加 


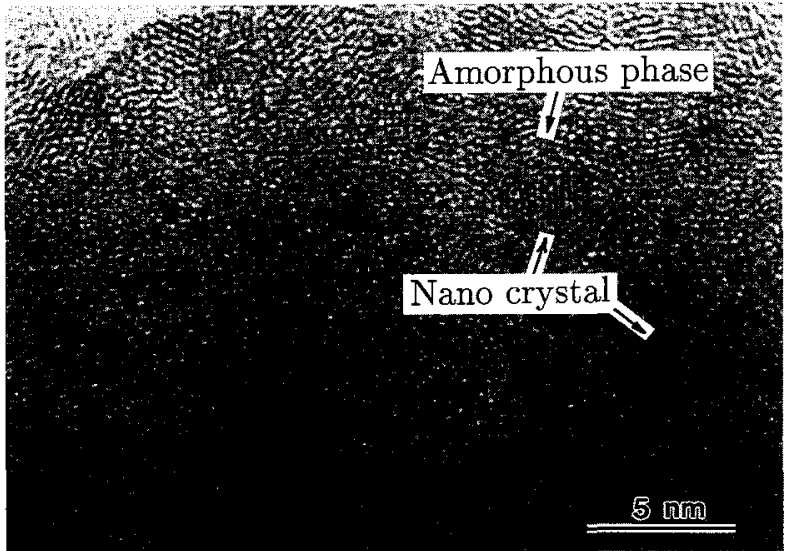

Fig. 1 TEM image of partially crystallized $\mathrm{Zr}_{55} \mathrm{Al}_{10} \mathrm{Cu}_{30} \mathrm{Ni}_{5}$ (at\%) bulk metallic glass.

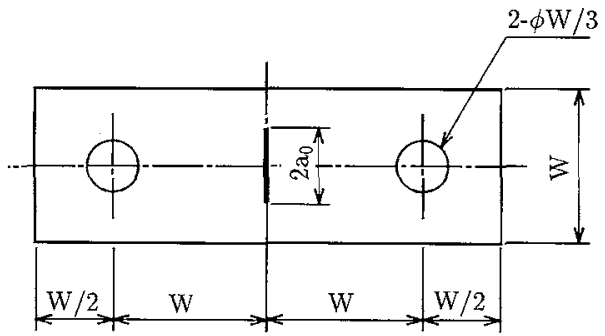

$\mathrm{W}=30 \mathrm{~mm}$, $\mathrm{t}=$ about $2 \mathrm{~mm}$

Fig. 2 Configuration of test specimen.

工後，表面を約 $30 \sim 60 \mu \mathrm{m}$ 電解研磨し，その後き裂発生筒 所となる切欠きを試験片中央に放電加工により導入した（長 巳 $2 a_{0}=12 \sim 15 \mathrm{~mm}$ ，幅 $200 \sim 400 \mu \mathrm{m}$ ，先端の曲率 50〜100 $\mu \mathrm{m})$. 放電加工終了後，さ裂開閉口を試験片のコンプライア ンス変化を用いて計測するため，き裂先端前方となる箘所に ひずみゲージを貼付けた。

試験機は電気油圧サーボ式疲労試験機を用いた。応力比 $R$ は0.1を主とし，き裂閉口がき裂進展に及ぼす影響を調べる ため一部 0 と0.3でも実施した。荷重繰返し速度 $f$ は $10 \mathrm{~Hz}$ とした。さ裂長さは，試験を中断して最大荷重の約 $50 \%$ の 荷重を負荷し，試験片表裹の左右計 4 䇢所でレプリカを採 りここれを金属顕微鏡 $(100$ 倍と500倍)で測定し，平均とし て求めた。予き裂長さは，奶欠さ底加ら $1 \mathrm{~mm}$ とした。

き裂開閉口は，前述したき裂先端前方に貼付けたひずみゲ ージの出力と試験機のロードセル出力を用いて, 除荷弾性コ ンプライアンス法7)で測定し，一部き裂先端後方約 $0.8 \mathrm{~mm}$ 以内でのき裂開口変位をレーザスペックルゲージ)でも求 め，コンブライアンス法で剆定した。レーザスペックルゲー ジによる測定時は一周期に100点のデータを採るため，採取 時のみ $f=0.1 \mathrm{~Hz}$ とした。

\section{3. 試験結果と検討}

\section{1 疲労き裂伝ぱ挙動}

破断後の試験片表面に招汁る低倍率写真例をFig. 3 亿示

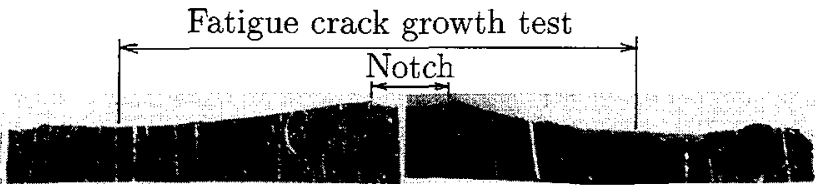

(a)

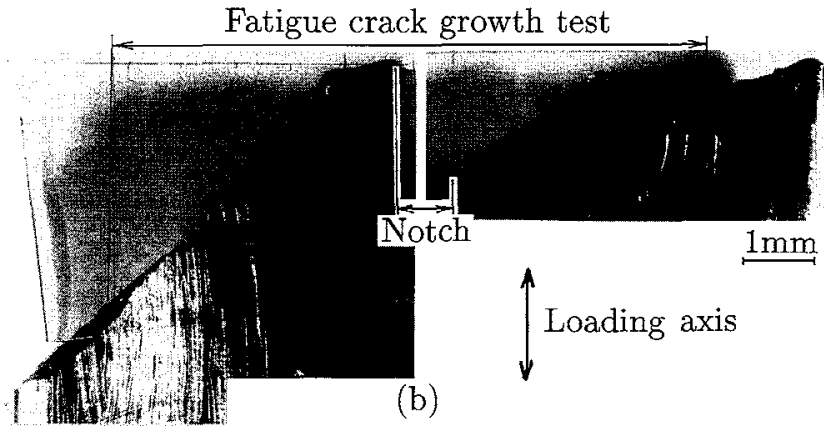

Fig. 3 Macroscopic crack propagation morphology on the specimen surfaces. (a) Vertical and (b) slant propagation.

す.き裂は(a)のように引張り軸にほぼ垂直な方向炕進展す るばかりでなく，(b)のように斜めに進展する場合も見られ た．金属顕微鏡 $(\times 800)$ による試験片表面に括けるき裂様相 例をFig. 4 に示す。（a)に示す垂直に伝ぱした場合， $d a / d n$ が約 $5 \times 10^{-6} \mathrm{~mm} /$ cycle 以下では，き裂縁执よび先端に执い て明瞭なすべり線は汪とんど見られず，き裂は直線的な伝ぱ を示した。 $d a / d n$ が $1 \times 10^{-5} \mathrm{~mm} / \mathrm{cycle}$ 程度以上では速度の 増加とともに，すべり線は長く数も增えて扣り，き裂はこの 中の主要なるのに沿って進展しているょらに見える。(b)の 斜めに伝ぱした場合も同様である。なお，き裂は鋼等の金属 結晶材の場合と同様，荷重の繰返しとともに安定的な成長を 示した。

引張り軸に垂直な万向とき裂進展方向の間の角度 $\theta$ と疲労 き裂伝ぱ速度 $d a / d n$ の関保を Fig. 5 飞示す，き裂は，20度 程度以内と $30 \sim 55$ 度程度傾斜したき裂が多く見られる。30 〜 55度程度傾斜したき裂は中間速度域に幾分集中して和り， $1 \times 10^{-6} \mathrm{~mm} /$ cycle 程度以下の低伝ば速度域で $\theta$ が小さくな る傾向があり，また $3 \times 10^{-5} \mathrm{~mm} / \mathrm{cycle}$ 程度以上の高伝ば速 度域でやはり $\theta$ が小さくなる傾向があるように見られる。

き裂が斜め集展する原因として，金属がラスは一つのせ 几断応力方向にすべり易いことが知られて和り，本材料もき 裂先端の平面ひず双下の最大世九断応力方向の一方にすべ り，そのすべりによる影響がき裂先端前方にすべり易い状態 になって残り9，次回の負荷でもまた方方にすべり，こ れを繰返したことが考觉られる。低伝ぱ速度域です，2つの 最大せん断応力方向のどちらか一方にすべり，き裂が進展す るが，中間速度域と比べ応力が小さいのでナノ結晶組織が障 害物となり10)，これにぶつかるともら一つの方向にすべり， これを繰返すことで比較的垂直な方向に進展したことが考兄 られる。また高伝ぱ速度域では，すべり量が大きいため温度 上昇を生じてすべり易くなり，2つの最大せん断応力方向で 同時にすべり，その結果として垂直方向に伝ぱしたことも考 えられる。今後，SEMによる詳細な破面観察や断面観察を 行って原因を検討する必要がある。 


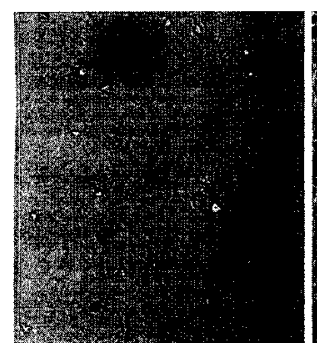

$5 \times 10^{-6} \mathrm{~mm} / \mathrm{cycle}$

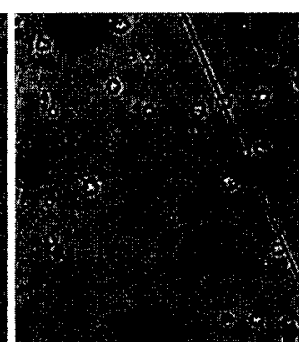

$1 \times 10^{-5}$

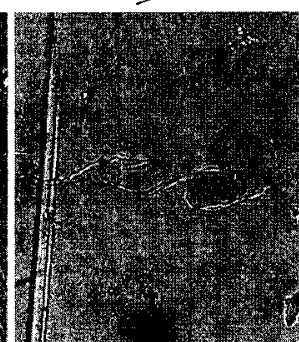

$3 \times 10^{-5}$

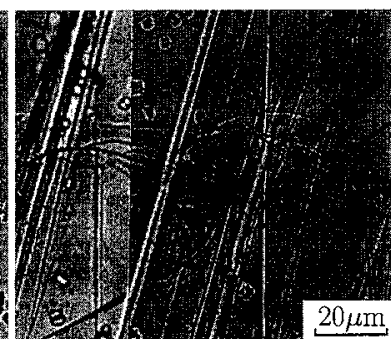

$1 \times 10^{-4}$

(a)
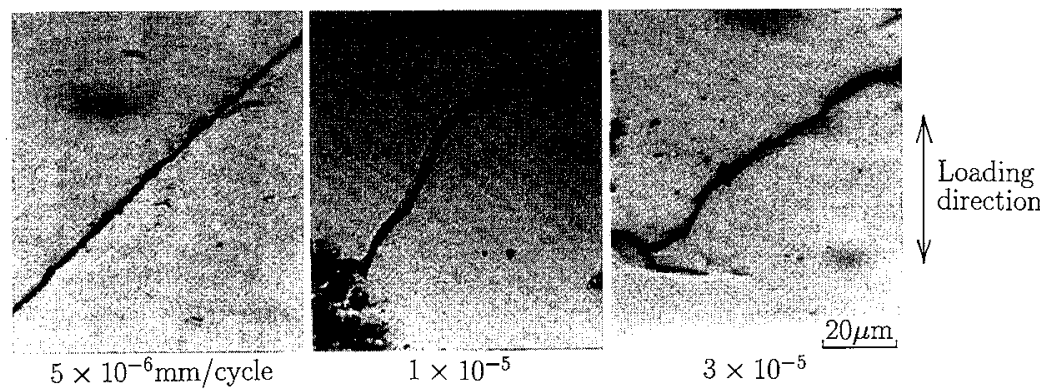

(b)

Fig. 4 Microscopic crack propagation morphology on the specimen surface. (a) Vertical and (b) slant propagation.

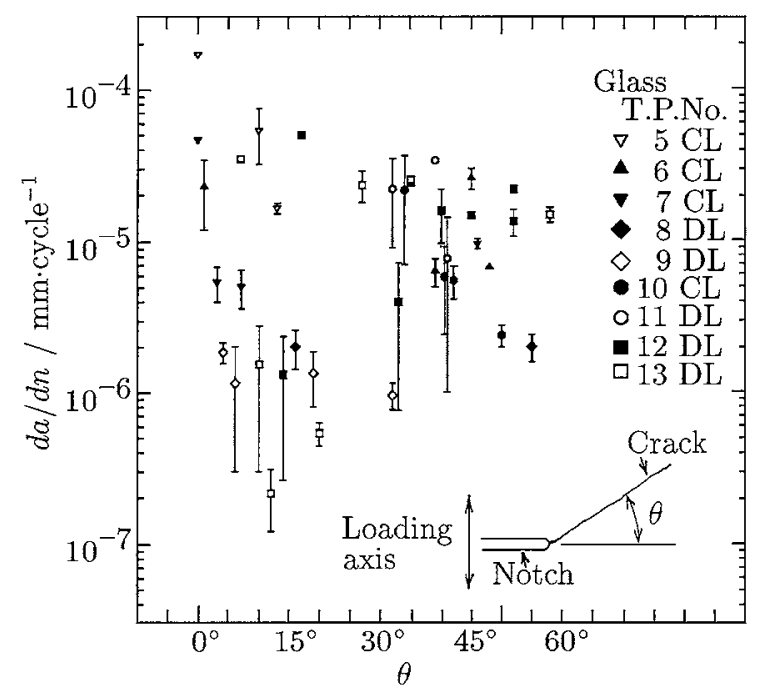

Fig. 5 Relation between $d a / d n$ and inclined angle $\theta$.

き裂が斜めに進展する場合は，モードＩともードII の混合 モードとなるが，モードI と混合モード下の疲労き裂伝ぱ速 度を統一的に精度よく表し光る破壊力学パラメータはないの が現状であるため11)ここではよく使われる方法として， き裂長さは引張り軸に垂直方向に投影した長さとし，モード I 型のき裂として評価した。

\section{2 疲労き裂伝ぱ速度 $d a / d n$ と $\Delta K / E$ の関係}

応力拡大係数範囲 $\Delta K$ をヤング率 $E$ で除した $\Delta K / E$ と $d a l$ $d n$ の関係を Fig. 6 沉データ点で示す. 異なる材料間の $d a d d n$
は, $\Delta K / E$ を用いると比較的よく一致することが結晶材に打 いて知ら机ている。（a）代表的な構造用金属結晶材（低強度 鋼 (S15C), 超高強度鋼(S5C), $\mathrm{Al}$ 合金, $\mathrm{Ti}$ 合金)の結果 ${ }^{12)}$ と比較したるのであり（b)は他の研究者による $\mathrm{Pd}^{13)}, \mathrm{Ni}^{14)}$ 基単相薄帯アモルフ ア ス合金叔よび $\mathrm{Zr}_{41.2} \mathrm{Ti}_{13.8} \mathrm{Cu}_{12.5} \mathrm{Ni}_{10} \mathrm{Be}_{22.5}$ 単相バルク金属ガラス ${ }^{15)}$ の結果と比較したものである.

疲労き裂公ぱ下限界近傍のデータを求めるために荷重漸減 試験を行った。図中試験片番号(T.P.No.) 横のCL は荷重一 定試験を, DL は荷重漸減試験を示す。応力拡大俰数 $K$ の 勾配 $C(=1 / \Delta K(d \Delta K / d a))$ は $-1.0 \sim-0.32 \mathrm{~mm}^{-1}$ であり， 荷重減少率は $9 \%$, 同一荷重下でのき裂伝ば増分 $\Delta a$ は最小 時約 $0.1 \mathrm{~mm}$ とした. ASTM(規格647)推奨値は $C \geq-0.08$ $\mathrm{mm}^{-1}$ であるが，Cは-1 $\mathrm{mm}^{-1}$ 以上でも疲労き裂层ぱ下限 界応力拡大係数範囲 $\Delta K_{\mathrm{th}}$ 炕影響を及济さないことが知られ ている16). また $\Delta a$ は $0.5 \mathrm{~mm}$ 以上が推奖されているが， Table 1 亿示す荷重減少直後の同一荷重下に括汸る測定時毎

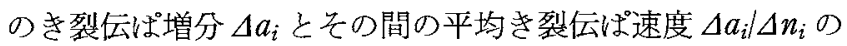
関係例で見られるように, $0.1 \mathrm{~mm}$ 以下の初回の $\Delta a_{1}=0.067$ $\mathrm{mm}$ から $\Delta a_{i} / \Delta n_{i}$ は浮湾一定であった。これは，本材料が高 強度なためき裂先端の塑性城寸法が小さく17), 荷重履稂の 影響を受ける領域が短いことによると考兄られる。

(a) 飞示すよらに Zr 基ナノ結晶分散バルク金属ガラスの $\Delta K_{\text {th }}$ は $\mathrm{Ni}$ 基単相薄帯アモルファス合金で報告されている $0.5 \mathrm{MPa} \sqrt{m}^{14)}$ 汇近く, 約 $0.9 \mathrm{MPa} \sqrt{m}$ とかなり小さい. 不安定破櫰を開始する疲学破壊勒性值 $K_{\mathrm{fc}}$ は的 $13 \mathrm{MPa} \sqrt{m}$ である。中間速度領域はパリス則が成り立って出り， $d a / d n$ は $\Delta K$ の約 2 乗に比例している.

$R=0$ と0.3の結果を見ると， $R=0$ のデータ点 $(\boldsymbol{O}$ 印)は $R$ 

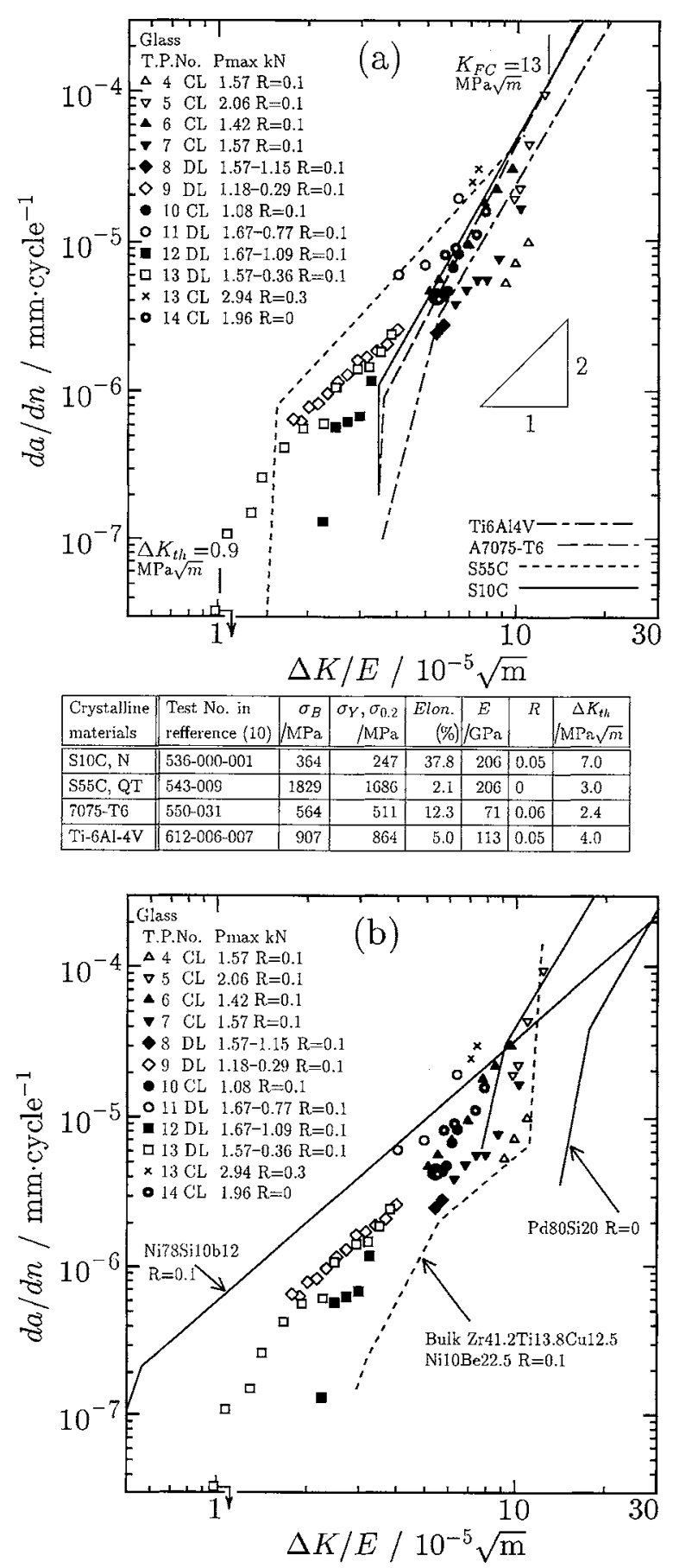

Fig. 6 Relation between $d a / d n$ and $\Delta K / E$. (a) Comparison with crystalline alloys and (b) with single phase amorphous alloys.

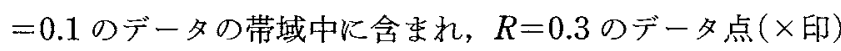
は $R=0.1$ のデータの带域上限にある.いずれるデータ点数 が少なく明確ではないが， $R=0$ では $R=0.1$ と平均応力に 明瞭な差が無いためであり，また $R=0.3 て ゙ は ~ R=0.1$ と比 べ引張りのより大きな平均応力のため, 結晶材で観察される 平均応力の効果と同様，より速い $d a / d n$ を示したと考光られ る.

$\Delta K_{\text {th }}$ 近傍学除くナノ結晶分散材の $d a / d n-\Delta K / E$ 関保は金

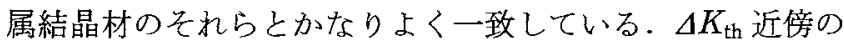
低伝ぱ速度域炕拈る $d a / d n$ は，低強度鋼 $(\mathrm{S} 15 \mathrm{C}), \mathrm{Al}$ 合金
Table 1 Relation between crack growth increment $\Delta a_{i}$ and the average fatigue crack growth rate $\Delta a_{i} / \Delta n_{i}$ in the same load range in load decrease stage.

\begin{tabular}{ccccc}
\hline$i$ & $1 \mathrm{st}$ & 2nd & 3rd & 4th \\
\hline$\Delta a_{i} / \mathrm{mm}$ & 0.067 & 0.075 & 0.125 & 0.122 \\
\hline $\begin{array}{c}\Delta a_{i} / \Delta n_{i} \\
/ \mathrm{mm} \cdot \mathrm{cycle}^{-1}\end{array}$ & $2.22 \times 10^{-6}$ & $2.50 \times 10^{-6}$ & $2.08 \times 10^{-6}$ & $2.45 \times 10^{-6}$ \\
\hline$\Delta K_{i} / \mathrm{MPa} \sqrt{m}$ & 4.51 & 4.55 & 4.61 & 4.69 \\
\hline
\end{tabular}

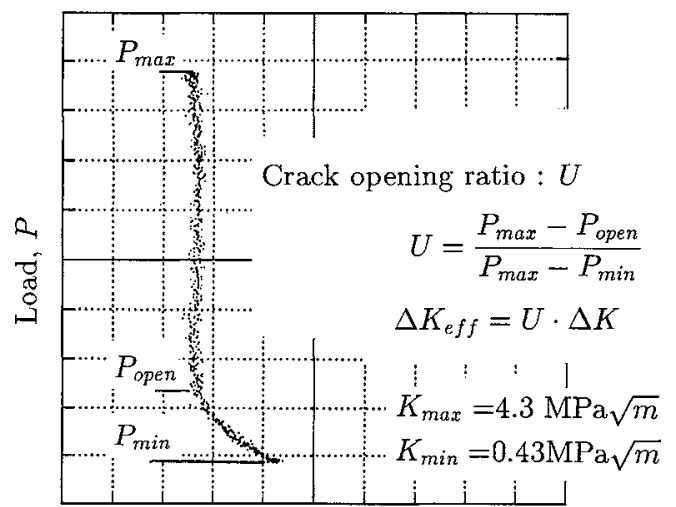

Strain Removed Unloading Elastic Component

Fig. 7 Load-strain hysteresis loop by the unloading elastic compliance method using strain gauge.

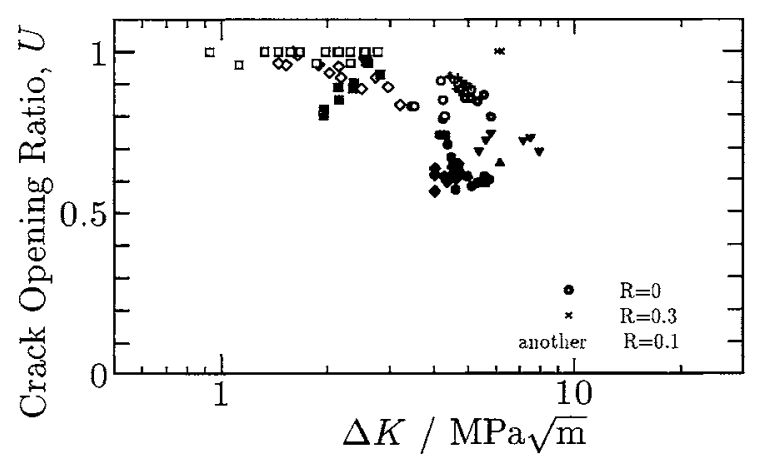

Fig. 8 Crack opening ratio $U$ as a function of $\Delta K$.

扎よび $\mathrm{Ti}$ 合金の同一 $\Delta K / E$ 值に対する $d a / d n$ と比べて大き いが，本材料之同等の引張り強度を有する超高強度鋼 (S55C)とは比較的よい一致を示している.

（b）を見ると，本 $\mathrm{Zr}$ 基ナノ結晶分散バルク金属ガラスの $d a / d n$ は，同一 $\Delta K / E$ 値に対して単相の薄帯アモルファス合 金およびバルク金属がラスの $d a / d n$ のほぼ中間にある。本材 料と同組成の単相バルク金属ガラスのき裂伝ぱデータは無い が，上記単相材と比較する限り，疲労き裂伝ぱ抵抗に及活す 䡛著なナノ結晶分散効果は見られないようである。

\section{3 疲労き裂伝ぱ速度 $d a / d n$ と $\Delta K_{\text {eff }} / E$ の関係}

き裂開閉口を測定するのに用いた荷重とき裂先端前方のひ ずみから除荷弾性成分を引いたひずみのヒステリシス例を Fig. 7 に示す. 同ヒステリシスより求めたき裂先端開口荷重 $P_{\text {open }}$ を基に，き裂開口比 $U$ を $\left(P_{\max }-P_{\text {open }}\right) /\left(P_{\max }-P_{\text {min }}\right) て ゙$ 求め, $\Delta K$ との関係を Fig. 8 K示寸，有効応力拡大係数範 


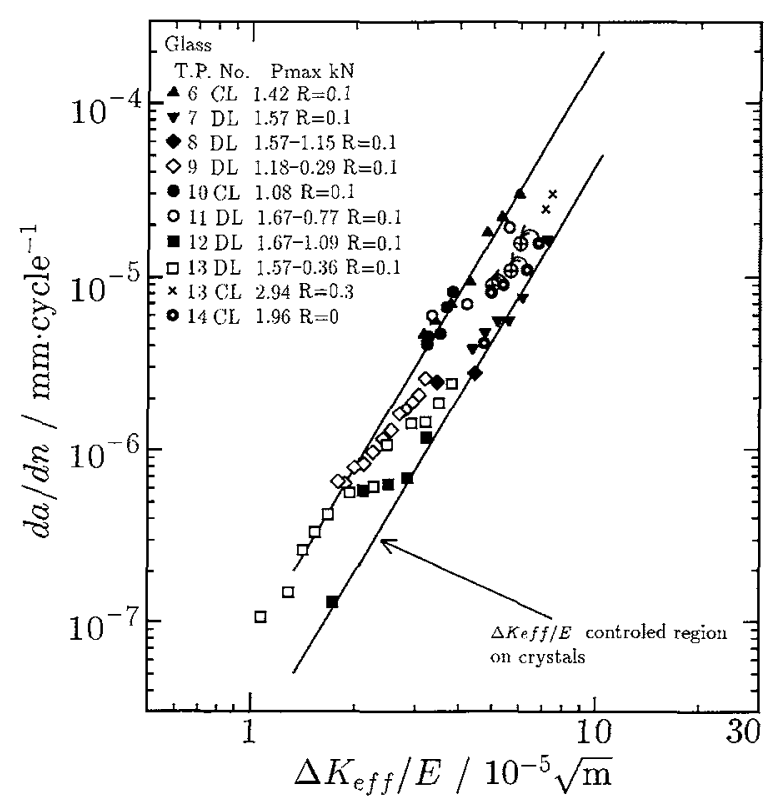

Fig. 9 Relation between $d a / d n$ and $\Delta K_{\text {eff }} / E$.

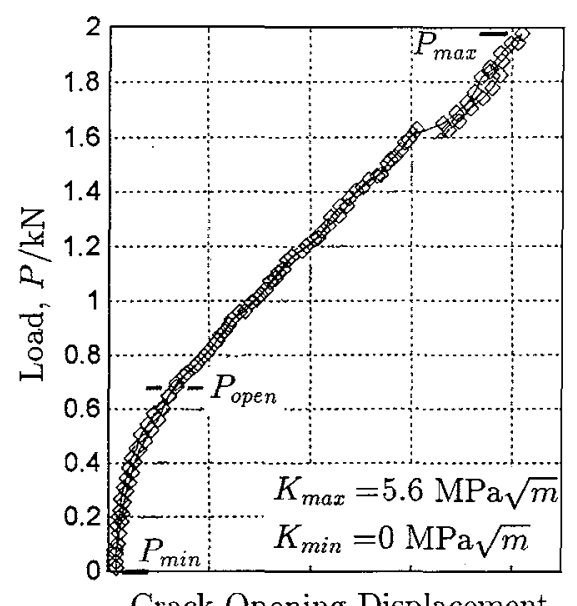

Fig. 10 Load-crack opening displacement hysteresis loop by the compliance method using a laser speckle gauge.

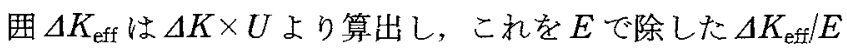
と $d a / d n$ の関係を Fig. 9 に示す。各種金属結晶材に打汀る $d a / d n$ は $\Delta K_{\text {eff }} / E$ Kよ，注后一義的炕表されることが知ら れて拉り，乙の関係を示す帯域 ${ }^{18)}$ 同図に実線で付記して いる. 本材料の結果怯, $\Delta K / E$ 線図に和いて $R=0 や 0.1 の$ $d a / d n$ K比べ少し大きかった $R=0.3 の d a / d n$ (×印)む含め, 同帯域中にほぼ含まれている。

$R=0$ に和いてレーザスペックルゲージを用いて求めたき 裂先端近傍の開口変位と荷重のヒステリシス例をFig. 10 K 示す．同図より $P_{\text {open }}$ を求め,ひずみゲージの場合と同様に して $\Delta K_{\mathrm{eff}} / E$ を求めた点をFig. 9 にや印で示す。き裂先端 近傍の開口变位を基に開閉口を求めたこの場合も，データ点 は各種金属結晶材が示す带域中にある。な技，ひずみゲージ を用いて得た $U$ 値は $f=10 \mathrm{~Hz}$ と $0.1 \mathrm{~Hz}$ で明瞭な差異ば見 られず19)，レーザスペックルゲージによる測定時に， $f$ を

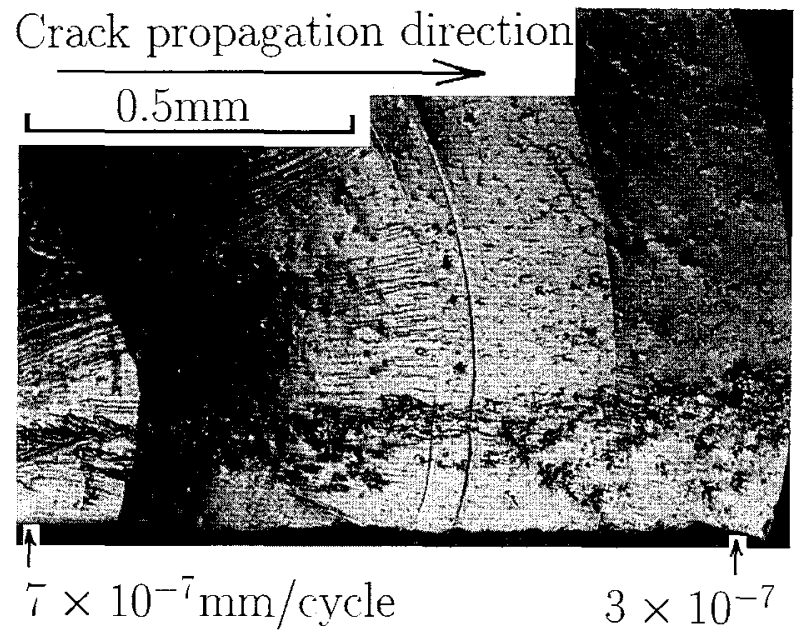

Fig. 11 Optical micrograph of the fracture surface near threshold.

$0.1 \mathrm{~Hz}$ に落とした $U$ 値に及ぼす影響は少ないと考えられる.

これらのことより，Zr 基ナノ結晶分散バルク金属ガラス そ怙いては $\Delta K_{\mathrm{eff}} / E$ 值が同じであれば，各種金属結晶材と同 じ疲労き裂伝ぱ抵抗を有していると言える。

$\Delta K / E$ 基に $\Delta K_{\text {th }}$ 近傍の低伀ば速度域を見大場合, 低強 度鋼, $\mathrm{A} 1$ 合金预よび Ti 合金と比べて本材料の $d a / d n$ はかな り大きい値を示した。しかし $\Delta K_{\text {eff }} / E$ 線図では一致して和 り，この差はき裂開閉口挙動の差と言克る。Fig. 8 を見る と， $\Delta K$ が小さくなるとともに，U值は大さくなって括り， $\Delta K_{\text {th }}$ 近傍では应济 1 になっている. $\Delta K_{\text {th }}$ 近傍の金属顕微鏡 破面写真例を Fig. 11 に示す。このような速度域に扣いて子 フレッティング酸化物による黒ずみは見られず，内部に款い てもき裂閉口が生じていないことを示唆している.金属結晶 材では，通常 $\Delta K$ が小さくなるとともに，U值は小さくな る20,21)。これは $\Delta K_{\text {th }}$ 近傍に和いてはフレッティングによる 酸化物誘起き裂閉口や，繰返し塑性域寸法が結晶粒徍等の組 織寸法と対応し，この影響を受けて破面の円凸る大きな り，破面荒さ誘起き裂閉口が大きくなるためである。本材料 に特いては，降伏応力が大きいため塑性誘起き裂閉口が小さ いのでフレッティングが生じにくく，また組織寸法が小さ い10)ので破面の円凸が小さくなり，破面荒さ誘起き裂閉口 も生じにくくなったことが考光られる。

\section{4. 結言}

$\mathrm{Zr}$ 基ナノ結晶分散バルク金属ガラスの疲労き裂伝ぱ挙動 を一部応力比も変光て実験的に険討した，得られた結果は以 下の通りである。

疲労き裂伝ぱ方向は，引張り軸に垂直な方向ばかりでな く，斜め方向のものも見られた，疲労き裂伝ぱ下限界応力拡 大係数範囲 $\Delta K_{\mathrm{th}}$ は約 $0.9 \mathrm{MPa} \sqrt{m}$ ，疲労破壊勒性估 $K_{\mathrm{fc}}$ は 約 $13 \mathrm{MPa} \sqrt{m}$ であり，これらの中間領域では疲労き裂伝ぱ 速度 $d a / d n$ は $\Delta K$ の約 2 乗に比例した。

$\Delta K$ をング率 $E$ で除した $\Delta K / E$ を基に，他の研究者に よる単相アモルフ ス ス材の $d a / d n$ と比べると顕著な差異は見 
られなかった。代表的な構造用金属結晶材の $d a / d n$ と比べる

と，低伝ぱ速度域に特いて低強度鋼，Al 合金执よび Ti 合金 よりも大きい值を示し，金属ガラスと同程度の強度を有する 超高強度鋼とはかなり近い値を示した。

き裂開閉口をき裂先端前方に貼付けたひずみゲージ出力， 叔よびき裂先端後方に当てたレーザスペックルダージ出力を 基にコンプライアンス法で測定して有効応力拡大俰数範囲 $\Delta K_{\text {eff }}$ 求めた。 $\Delta K_{\text {eff }} / E$ を基に各種金属結晶材の $d a / d n$ 亡 比べると，異なる応力比下の $d a / d n$ も含め注汪一致し， $\mathrm{Zr}$ 基ナノ結晶分散バルク金属ガラスの $d a / d n$ む, $\Delta K_{\text {eff }} / E$ を基 に金属結晶材の結果を用いて推定できることが示された。

$\Delta K_{\text {th }}$ が約 $0.9 \mathrm{MPa} \sqrt{m}$ と小さく，また低伝ぱ速度域に拉 いて超高強度鋼を除く金属結晶材と比べて大きい $d a / d n$ 值を 示したのは，金属ガラスは金属結晶材とは逆にこのような低 伝ぱ速度域に执いてき裂閉口が生じにくいためと考えられる。

\section{文献}

1) T. Masumoto: Materials Science of Amorphous Metals, Ohmsha, Tokyo, (1982), pp. 1-20.

2) A. Inoue, K. Kita, T. Zhang and T. Masumoto: Mater. Trans., JIM, 30(1989), 722-725.

3) A. Inoue: Mater. Sci. Eng., A179/A180(1994), 57-61.

4) T. Zhang and A. Inoue: Mater. Trans., JIM, $\mathbf{3 9}(1998), 1230$ 1237.

5) Y. Yokoyama, K. Yamano, K. Fukaura, H. Sunada and A. Inoue: Mater. Trans., JIM, 40(1999), 1015-1018.
6) T. Zhang and A. Inoue: Collected Abstracts of the 1999 Spring Meeting of the Japan Inst. Metals, (1999), p. 185.

7) M. Kikukawa, M. Jono, K. Tanaka and M. Takatani: J. Soc. Mater. Sci., Jpn., 25 (1976), 899-903.

8) I. Nishikawa, K. Ogura, M. Yamagami and K. Kuwayama: J. Soc. Mater. Sci., Jpn., 43(1994), 1290-1296.

9) M. Nagumo: J. Mater. Sci. Soc. Jpn., 15 (1978), 200-206.

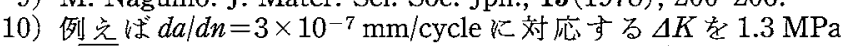
$\sqrt{m}$, 降伏応力 $\sigma_{Y}$ を $1.7 \mathrm{GPa}$ として, 平面ひずみ下の繰返し 塑性域寸法 $r_{c p}$ は $1 / 3 \pi\left(\Delta K / 2 \sigma_{Y}\right)^{2}=15 \mathrm{~nm}$ となる.ナノ結晶と その回りのアモルフ、ス相を含めた組織寸法は10 nm 程度で めり， $r_{\mathrm{cp}}$ はこれ之近く，障害物になりえると思わ礼る。

11) B. R. You and S. B. Lee: Fatigue Fract. Eng. Mater. Struct., 21(1998), 1037-1048.

12) Data book on fatigue crack growth rates of metallic materials, ed. by M. Jono, Soc. Mater. Sci., Jpn., (1983).

13) T. Ogura, T. Masumoto and K. Fukushima: Scripta Metall., 9 (1975), 979-983.

14) A. T. Alpas, L. Edwards and C. N. Reid: Metall. Trans. A, 20A (1989), 1395-1409.

15) R. O. Ritchie, C. J. Gilbert and V. Schroeder: Proc. Int. Conf. on Advance Technology in Experimental Mechanics '99, Vol. 1, (JSME-MMD, 1999), pp. 9-15.

16) A. Ohta, E. Sasaki and M. Kosuga: Trans. Jpn. Soc. Mech. Eng., 43(1977), 3179-3191.

17）最も大きな単純引張りの平面応力下の塑性域寸法でも， $K_{\max }=$ $5 \mathrm{MPa} \sqrt{m}, \sigma_{Y}=1.7 \mathrm{GPa}$ として, $\pi / 8\left(K_{\max } / \sigma_{Y}\right)^{2}=$ 約 $3 \mu \mathrm{m}$ で ある。

18) T. Ogawa, K. Ohya and K. Tokaji: J. Soc. Mater. Sci., Jpn., $41(1992), 502-508$.

19）例穴ば $R=0, \Delta K=5.6 \mathrm{MPa} \sqrt{m}$ に执いて， $f=10$ と $0.1 \mathrm{~Hz}$ の $U$ 值はいずれす 0.86 であった。

20) S. Suresh, G. F. Zamiski and R. O. Ritchie: Metall. Trans. A, 12A (1981), 1435-1443.

21) H. Kobayashi, T. Ogawa, H. Nakamura and H. Nakazawa: Trans. Jpn. Soc. Mech. Eng. Ser. A, 50(1984), 309-319. 